\title{
Clinical significance of K-ras oncogene activation in ampullary neoplasms
}

C H Chung, R E Wilentz, M M Polak, T B Ramsoekh, L A Noorduyn, D J Gouma, K Huibregtse, G J A Offerhaus, R J C Slebos
Department of Pathology, Academic Medical Centre, University of Amsterdam, Amsterdam, The Netherlands C H Chung R E Wilentz R M Polak T B Ramsoekh L A Noorduyn G J A Offerhaus R J C Slebos

Department of Surgery D J Gouma

Department of Gastroenterology K Huibregtse

Department of Pathology, The Johns Hopkins Medical Institutions, Baltimore, Maryland, USA

R E Wilentz

Correspondence to: Robbert J C Slebos, PhD, Academic Medical Centre, Academic Medical Centre, Department of Pathology, Meibergdreef 9 , $1105 \mathrm{AZ}$ Amsterdam The Netherlands.

Accepted for publication 29 February 1996

\begin{abstract}
Aims-To investigate the prevalence of $\mathrm{K}$-ras codon 12 point mutations in ampullary neoplasms, to explore their clinical usefulness, and to test whether the detection of these mutations could be used to identify ampullary malignancies at an early stage.

Methods-Forty one tumour specimens from 28 patients with ampullary neoplasms were analysed for activating point mutations in $\mathrm{K}$-ras codon 12 using a sensitive polymerase chain reaction (PCR) based assay.

Results-Eleven (39\%) of the 28 primary tumours harboured point mutations in $\mathrm{K}$-ras. Mutations were identified in seven $(41 \%)$ of the 17 carcinomas and four $(36 \%)$ of the 11 adenomas. Four of the possible six permutations in codon 12 were found in these 11 samples. This spectrum of mutations is different from pancreatic carcinoma but resembles that of colorectal neoplasms. Cytological brush specimens were available in 11 cases, and in all of these specimens, the $\mathrm{K}$-ras status in the primary tumour and brush specimens was identical.

Conclusions-K-ras codon 12 point mutations occur in about $40 \%$ of ampullary neoplasms at a relatively early stage in tumorigenesis. The pattern of mutations in these tumours resembles that of the adenoma-carcinoma sequence in the colorectum. These results indicate that ampullary neoplasms can be detected at an early stage by searching for genetic alterations in the K-ras oncogene in cytological brush specimens.

(F Clin Pathol 1996;49:460-464)
\end{abstract}

Keywords: ampullary neoplasms, K-ras, point mutation, brush cytology, endoscopic retrograde cholangiopancreatography.

Ampullary neoplasms originate from the epithelial cells of the ampullary mucosa, and account for a minority of all gastrointestinal neoplasms. Ampullary epithelial neoplasms include pre-invasive and invasive tumours in the region of the ampulla of Vater. ${ }^{1}$ It is of clinical importance that neoplasms of the ampulla of Vater be differentiated from other periampullary carcinomas, such as those arising in the distal common bile duct or head of the pancreas, because ampullary carcinomas have a significantly better prognosis than the other periampullary neoplasms. The five year survival after pancreaticoduodenectomy (Whipple's operation) for ampullary carcinoma is about $50 \%$, compared with $15-20 \%$ for bile duct (cholangiocarcinoma) and pancreatic carcinoma under the most favourable conditions. ${ }^{2-4}$ Ampullary carcinomas seem to arise from precancerous lesions in an adenoma-carcinoma sequence. ${ }^{156}$ Morphological evidence for such a sequence is based on the presence of adenomatous areas adjacent to infiltrating carcinomas and on the identification of foci of malignant cells within some adenomas.

At present, most patients with ampullary neoplasms are identified on the basis of symptoms such as jaundice, pain, and/or weight loss. The diagnostic procedures most frequently used are ultrasonography, computed tomography (CT) , and endoscopic retrograde cholangiopancreatography (ERCP). The latter is especially useful for establishing the diagnosis of neoplasms in the region of the ampulla, because cytological brushings or biopsy specimens can be obtained easily during the procedure. In our hospital cytological brushing is the preferred methodology for tissue diagnosis, and these samples form a source of neoplastic cells that can be classified by either conventional light microscopy or analysed by newer methods aimed at detecting specific genetic alterations in these cells. ${ }^{78}$

Because of the low incidence of ampullary neoplasms, relatively little is known about specific genetic alterations that occur in these lesions. Inactivating mutations in the p53 tumour suppressor gene have been described, as have activating point mutations in the K-ras oncogene. ${ }^{910}$ The ras oncogenes are among the most frequently activated oncogenes encountered in human cancer. Three ras oncogenes have been described: the Harvey-, the Kiersten-, and N-ras genes (for review se $^{11}$ ). These genes encode closely related proteins that can acquire transforming potential when altered at one of the critical positions at codons 12,13 , or 61 . An activating point mutation in $\mathrm{K}$-ras codon 12 is the most common oncogene alteration in human adenocarcinomas (for review $s^{12} e^{12}$. Two previous studies have investigated the incidence of ras mutations in ampullary neoplasms. In the first report only two of 15 neoplasias harboured point mutations in $\mathrm{K}-\mathrm{ras}^{10}$; in a second six of 17 ampullary tumours harboured ras mutations (five $\mathrm{K}$ - and 
one $\mathrm{N}$-ras). ${ }^{913}$ We limited our investigation to $\mathrm{K}$-ras codon 12 point mutations because these are by far the most frequent oncogene mutations in human solid tumours ${ }^{12}$ and because they occur in the majority of carcinomas from the head region of the pancreas.

\section{Methods}

TISSUE SELECTION AND STAGING

Records of all patients with an ampullary neoplasm diagnosed by endoscopic biopsy between 1987 and 1995 at the Academic Medical Centre, Amsterdam, were reviewed. Only surgically treated patients were included in the study. Twenty eight patients met this criterion; 19 were treated by pancreaticoduodenectomy (Whipple's operation), either with or without preservation of the pylorus, and nine by local resection of the ampulla of Vater. Age at diagnosis, gender, and tumour size were ascertained from the pathology records.

Since 1993, the distal common bile ducts of all Whipple resection specimens received by the Department of Pathology, Academic Medical Centre, have been routinely brushed to obtain cells for cytological examination and molecular analysis. Brush cytology specimens were also obtained during a diagnostic or therapeutic ERCP procedure from a number of patients presenting with tumours in the head region of the pancreas. ${ }^{7}{ }^{14}$ Brush samples from Whipple resection specimens were available for 11 of the 19 patients; two of these patients had prior cytological brushings obtained during ERCP. Thus, a total of 41 specimens was available for study.

\section{TISSUE PREPARATION AND DNA ISOLATION}

Archival specimens of ampullary carcinomas were cut into $5 \mu \mathrm{m}$ sections and mounted on glass slides. Tumour cells were carefully microdissected away from the stroma ${ }^{15}$ and collected in microcentrifuge tubes with 50-200 $\mu \mathrm{l}$ DNA isolation buffer (10 mM TRIS- $\mathrm{HCl}, \mathrm{pH} \mathrm{8}$, $0.2 \%$ Tween-20, and $100 \mathrm{mg} / \mathrm{ml}$ proteinase $\mathrm{K}$ ). Cells obtained by brushing were collected by centrifugation and resuspended in $300 \mu \mathrm{l}$ DNA isolation buffer. The samples were then incubated for 16-18 hours (archival specimens) or one hour (brush samples) at $56^{\circ} \mathrm{C}$. Proteinase was inactivated by denaturation for 10 minutes at $95^{\circ} \mathrm{C}$, and the resulting samples were used directly for polymerase chain reaction (PCR) amplification. All analyses for K-ras codon 12 mutations were performed in duplicate on two independently isolated DNA specimens.

DETECTION OF K-RAS CODON 12 MUTATIONS

The analysis of point mutations in K-ras codon 12 was carried out using a modified version of a previously described protocol. ${ }^{16} \mathrm{~K}$-ras point mutations were evaluated by amplification of the sample DNAs, restriction enzyme digestion using MvaI (an isoschizomer of BstNI; Boehringer Mannheim, Mannheim, Germany), reamplification of the digested and undigested PCR products, and allele specific oligodeoxynucleotide (ASO) hybridisation. For the first round of amplification, tumour DNA was amplified for 15 cycles with primers A (5'-ACT
Table 1 Clinical and pathological parameters of the 28 patients with ampullary neoplasms with respect to $K$-ras codon 12 point mutations

\begin{tabular}{lll}
\hline Parameter & $K$-ras negative & $K$-ras positive \\
\hline $\begin{array}{l}\text { Age at diagnosis (years) } \\
\quad \text { Median (range) }\end{array}$ & $68(29-78)$ & $68(53-73)$ \\
$\begin{array}{l}\text { Gender } \\
\text { Male }\end{array}$ & 11 & 4 \\
$\quad$ Female & 6 & 7 \\
Tumour type & 7 & \\
$\quad$ Adenoma & 10 & 4 \\
$\quad$ Carcinoma & 7 \\
Resection type & 6 & 3 \\
$\quad$ Local & 11 & 8 \\
$\quad$ Whipple & & \\
\hline
\end{tabular}

GAA TAT AAA CTT GTG GTA GTT GGA CCT-3') and D (5'-TCA TGA AAA TGG TCA GAG AAA CC-3'). This PCR product was then digested with MvaI to concentrate the mutant K-ras DNA fragments. Subsequently, a second round of PCR was carried out on both the digested and undigested first round PCR products. In the second round PCR, DNA was amplified for 35 cycles using primers $A$ and $B$ (5'-TCA AAG AAT GGT CCT GGA CC-3'). After denaturation the undigested and digested PCR products were spotted onto seven different nylon membranes (Genescreen Plus, NEN Research Products, Boston, Massachusettes, USA) and hybridised to each of the K-ras codon 12 specific oligodeoxynucleotides, as described previously. ${ }^{17}$ Positive controls comprised plasmid clones harbouring each of the possible sequence variations in codon 12. Final stringency washes were carried out at $63^{\circ} \mathrm{C}$, followed by autoradiography.

\section{Results}

The clinical and pathological parameters of the 28 patients ( 15 men and 13 women) studied are summarised in table 1 .The median age at diagnosis was 68 years (range 29-78 years). Nine patients were treated by local resection and 19 underwent a Whipple resection procedure. Eleven patients had ampullary adenomas and 17 had infiltrating adenocarcinoma of the ampulla.

Activating point mutations in $\mathrm{K}$-ras codon 12 were found in $11(39 \%)$ of the 28 patients. An example of an analysis for K-ras point mutations is presented in fig 1 . Four $(36 \%)$ of the 11 adenomas and seven (41\%) of the 17 carcinomas harboured activating mutations in $\mathrm{K}$-ras codon 12. Four of the possible six permutations that activate the $\mathrm{K}$-ras oncogene were found. In adenomas the wild-type codon GGT (glycine) was mutated to GAT (aspartic acid) in two patients, to TGT (cysteine) in one and to GCT (alanine) in another. In infiltrating carcinomas the corresponding mutations were GAT (aspartic acid) in three patients, TGT (cysteine) in two and GTT (valine) in two. In all patients the signal obtained with the mutation specific oligodeoxynucleotide probe was clearly visible in the unenriched sample. A stronger signal was always obtained when the mutation enriched PCR product was probed.

The presence or absence of $\mathrm{K}$-ras point mutations was not significantly $(p>0.05)$ different between patients of different ages or 
gender (table 1). Accurate information on tumour size was available for only 16 patients, five with adenomas and 11 with carcinomas. Although these numbers are small, K-ras point mutations were found in two of three adenomas $>2 \mathrm{~cm}$ in diameter, but not in the two adenomas $<2 \mathrm{~cm}$. Three of six carcinomas $>2$ $\mathrm{cm}$ harboured $\mathrm{K}$-ras mutations compared with only one of five of those $<2 \mathrm{~cm}$.

Because of the importance of ERCP in the diagnosis of ampullary neoplasms, the possibility of identifying these tumours on the basis of their genetic alterations in the K-ras oncogene in ERCP brush specimens was explored. For this purpose, cytological brushings from the common bile duct of 11 Whipple resection specimens were collected. The primary neoplasms harboured an activating point mutation in K-ras in four of these 11 samples (table 2). In these four patients, the same mutation was also detected in the brush specimen, while only wild-type K-ras was found in the brush specimens from the seven patients with no mutation in the primary tumour.

The results of the analyses of brush cytology specimens obtained from Whipple resection specimens for K-ras mutations are summarised in table 2. Two of the patients (cases 20 and 21) had previously undergone an ERCP, and these brush samples were also analysed. In both patients, K-ras analysis for the primary tumour was identical with that for the brush samples: no mutation was found in the ERCP brush sample from case 20, while a GAT (aspartic acid) mutation was found in the sample from case 21. Conventional light microscopy of the two ERCP brush samples revealed malignant cells in the specimen from case 20; cytology was negative in the specimen from case 21 .

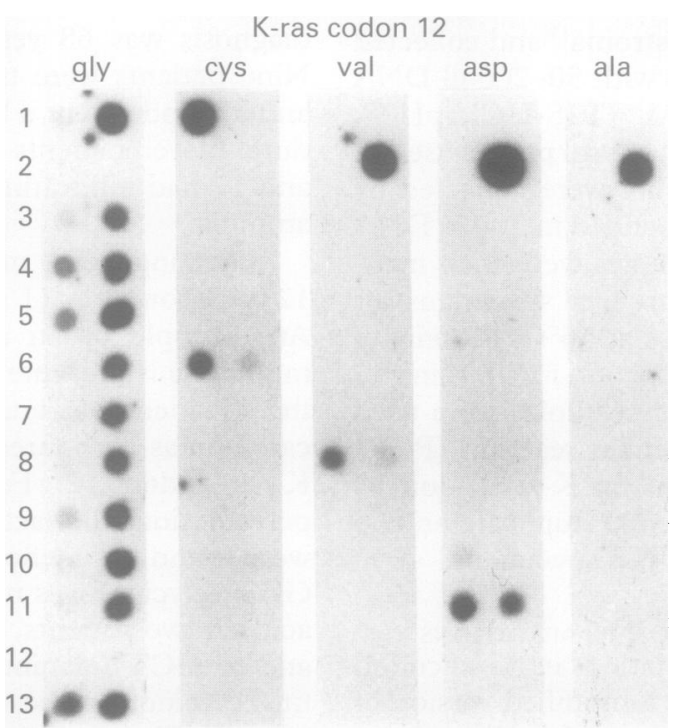

Figure 1 Analysis of $K$-ras codon 12 point mutations in primary ampullary adenocarcinomas and in ampullary adenomas. Right column: mutation unenriched PCR products, left column: mutation enriched PCR products. Row 1, positive control for K12 cys mutant (left column), positive control for K12 wild-type (right column); row 2, positive controls for $\mathrm{K} 12 \mathrm{val}$, asp, and ala mutants (right column); rows 3 to 11 , cases $11,12,13,15,16,17,19,20$ and 21; lane 12, buffer-only (negative) control; lane 13: placenta DNA. For rows 3 to 13 , the unenriched PCR product is in the right column and the mutant enriched $P C R$ product is in the left.
Table $2 K$-ras status in primary ampullary carcinomas and brush specimens from 11 patients who underwent a Whipple resection

\begin{tabular}{|c|c|c|c|c|}
\hline $\begin{array}{l}\text { Case } \\
\text { number }\end{array}$ & Gender & $\begin{array}{l}\text { Age } \\
\text { (years) }\end{array}$ & $\begin{array}{l}\text { Primary } \\
\text { tumour }\end{array}$ & Brush specimen \\
\hline 11 & Male & 75 & Wild-type & Wild-type \\
\hline 13 & Female & 70 & Cysteine & Cysteine \\
\hline 20 & Male & 50 & Wild-type & Wild-type* \\
\hline 21 & Male & 73 & Aspartic acid & Aspartic acid ${ }^{\star}$ \\
\hline 22 & Female & 61 & Aspartic acid & Aspartic acid \\
\hline 23 & Male & 37 & Wild-type & Wild-type \\
\hline 24 & Female & 78 & Wild-type & Wild-type \\
\hline 25 & Male & 70 & Wild-type & Wild-type \\
\hline 26 & Female & 70 & Cysteine & Cysteine \\
\hline 27 & Male & 73 & Wild-type & Wild-type \\
\hline 28 & Female & 68 & Wild-type & Wild-type \\
\hline
\end{tabular}

*The same $\mathrm{K}$-ras status was found in the preoperative ERCP brush specimen.

\section{Discussion}

The diagnosis of a neoplasm of the ampulla of Vater presents problems for several reasons. It may be difficult to establish the neoplastic nature and extent of the lesion preoperatively, and once a neoplastic diagnosis is established, it can be difficult to distinguish these tumours from other tumours that arise in the head region of the pancreas. ${ }^{18}$ The former is especially important as surgical removal of the neoplasm can cure a significant number of patients. $^{3}{ }^{19} 20$ Markers that could predict neoplastic growth, tumour type, or extent would be of great benefit.

Histological observation suggests that ampullary neoplasms develop via the adenomacarcinoma sequence, eventually evolving into invasive cancer. ${ }^{61}$ Vogelstein $e t a l^{2}$ postulated that for colorectal carcinomas this adenomacarcinoma sequence is associated with the accumulation of genetic alterations in cancer causing genes. In this model point mutations in ras oncogenes were less frequent in early colonic adenomas than in invasive carcinomas. In the present study point mutations in K-ras were found in both adenomas and carcinomas, which suggests that K-ras activation occurs relatively early in this sequence. It has been reported that the risk of the development of carcinoma is significantly larger in ampullary adenomas than in duodenal adenomas $(42 \% v$ $9 \%$ respectively). ${ }^{1}$ The pattern of K-ras point mutations in ampullary neoplasms is not predictive of such a development, as the proportion of $\mathrm{K}$-ras positive specimens is roughly equal in both adenomas and carcinomas. In colorectal carcinomas $42 \%$ of the adenomas without carcinoma had a mutation in a ras oncogene, and $57 \%$ of adenomas that harboured foci of carcinoma also harboured such mutations. ${ }^{22}$ The frequency of ras mutations was especially high in large $(>2 \mathrm{~cm}$ ) adenomas $(60-100 \%)$ compared with adenomas $<2 \mathrm{~cm}$ in diameter $(12-20 \%)$. The frequencies observed in the present study are very similar: point mutations in $\mathrm{K}$-ras seem to be equally frequent in adenomas and carcinomas $>2 \mathrm{~cm}$ and are less frequent in adenomas $<2 \mathrm{~cm}$. However, the number of cases for which this information was available was small. Patient age and gender were not associated with the presence/absense of K-ras point mutations. 
Interestingly, the spectrum of K-ras codon 12 mutations in ampullary neoplasms not only resembles that seen in colorectal neoplasms but is also more diverse than the pattern observed in pancreatic carcinoma. Four of the possible six nucleotide substitutions at codon 12 that activate the $\mathrm{K}$-ras oncogene were found in the ampullary samples: $G$ to $A$ transitions and $\mathrm{G}$ to $\mathrm{T}$ transversions each accounted for $45 \%$ of the mutations; $G$ to $C$ transversions were found in $9 \%$ of the patients. This pattern is almost identical with that found in neoplasms of the colon and rectum. ${ }^{23}$ In contrast, about $60 \%$ of $\mathrm{K}$-ras point mutations in pancreatic carcinoma are $G$ to $A$ transitions in the second position of codon $12 .^{1624}$

In summary, the pattern of K-ras point mutations in ampullary neoplasms suggests an aetiology that resembles that of colorectal cancer more closely than that of pancreatic cancer. In fact, the clinical experience of the relatively indolent biology of these neoplasms is also more similar to colorectal carcinoma than the aggressive growth of pancreatic carcinoma and cholangiocarcinoma.

Motojima et $a l^{10}$ suggested that ampullary carcinoma may be distinguished from pancreatic cancer on the basis of the low incidence of $\mathrm{K}$-ras point mutations in the latter. In a study from Japan, only two (13\%) of the 15 ampullary carcinomas harboured point mutations in K-ras codon 12. In our study, however, we found an incidence of $\mathrm{K}$-ras point mutations of about $40 \%$ in ampullary carcinomas, while about $35 \%$ of the ampullary adenomas harboured $\mathrm{K}$-ras point mutations. In another study from Europe, K-ras point mutations were found in six (35\%) of 17 ampullary tumours. ${ }^{13} \mathrm{~A}$ possible explanation for these discrepant results may be ethnic differences between the groups in which these studies were conducted, or the choice of the technique used to study activating ras mutations. Specifically, the microdissection of neoplastic cells away from normal non-neoplastic cells has proven to be an essential step for improving the sensitivity of detection of genetic alterations in human neoplasms. ${ }^{15}$

Ampullary neoplasms are ideally suited for detection by ERCP because of their location. As routine cytology of ERCP brush specimens does not always identify malignant processes, ${ }^{14}$ the detection of genetic alterations in these specimens could be a valuable addition to classic light microscopy. The use of K-ras point mutations as a genetic marker is particularly attractive because of the high incidence of these mutations in human malignancies and the relative ease by which they can be detected..$^{25}{ }^{26}$ Examples of such applications for tumours in the region of the head of the pancreas include the analysis of K-ras mutations in DNA isolated from stool, ${ }^{15}$ pancreatic juice, ${ }^{27}{ }^{28}$ or ERCP brushings. ${ }^{29}$ The combination of PCR amplification followed by ASO hybridisation can be carried out routinely, ${ }^{17}$ with a sensitivity that can be increased by selective amplification of the mutant K-ras PCR products. ${ }^{16}$ Our results show the feasibility of applying this approach to cytological brush samples of ampullary tumours.
In conclusion, activating point mutations in codon 12 of the K-ras oncogene are frequent events in ampullary neoplasms and occur in a pattern that more closely resembles colorectal neoplasia than pancreatic carcinoma. K-ras mutational analysis of cytological brush specimens obtained during ERCP may supplement diagnosis of ampullary neoplasms by light microscopy.

The authors wish to thank Dr R H Hruban for his suggestions on the manuscript, Professor $F$ ten Kate for his assistance in reviewing the slides, and Alex Musler for technical assistance.

1 Seifert E, Schulte F, Stolte M. Adenoma and carcinoma of the duodenum and papilla of Vater: a clinicopathologic study. $A m$ f Gastroenterol 1992;87:37-42.

2 Lerut JP, Gianello PR, Otte JB, Kestens PJ. Pancreaticoduodenal resection. Surgical experience and evaluation of risk factors in 103 patients. Ann Surg 1984;199:432-7.

3 Crist DW, Cameron JL. The current status of the Whipple operation for periampullary carcinoma. Adv Surg 1992; 25:21-49.

4 Tsao JI, Rossi RL, Lowell JA. Pylorus-preserving pancreaticoduodenectomy. Is it an adequate cancer operation?. Arch Surg 1994;129:405-12.

5 Nordback IH, Hruban RH, Cameron JL. Second primary lesions in the biliary tree after successful resection of ampullary carcinoma. Surgery 1992;112:111-15.

6 Gouma DJ, Obertop H, Vismans J, Willebrand D, Soeters PB. Progression of a benign epithelial ampullary tumor to PB. Progression of a benign epithelial ampula

7 Huibregtse K, Smits ME. Endoscopic management of diseases of the pancreas. Am F Gastroenterol 1994;89:S6677.

8 van Es JM, Polak MM, van den Berg FM, Ramsoekh TB, Craanen ME, Hruban RH, Offerhaus GJA. Molecular markers for diagnostic cytology of neoplasms in the head of the pancreas: mutation of K-ras and overexpression of the p53 gene product. $\mathcal{F}$ Clin Pathol 1995;48:218-22.

9 Scarpa A, Capelli P, Zamboni G, Oda T, Mukai K, Bonetti $F$, et al. Neoplasia of the ampulla of Vater. Ki-ras and p53 F, et al. Neoplasia of the ampulla of Vater.

10 Motojima K, Tsunoda T, Kanematsu T, Nagata Y, Urano T, Shiku $H$. Distinguishing pancreatic carcinoma from other periampullary carcinomas by analysis of mutations in the Kirsten-ras oncogene. Ann Surg 1991;214:657-62.

11 Barbacid M. ras genes. Annu Rev Biochem 1987;56:799827.

12 Bos JL. ras oncogenes in human cancer: a review. Cancer Res 1989;49:4682-9.

13 Scarpa A, Zamboni G, Achille A, Capelli P, Bogina G, Iacono C, et al. ras-family gene mutations in neoplasia of the ampulla of Vater. Int $\mathcal{F}$ Cancer 1994;59:39-42.

14 Sivak MV. Clinical and endoscopic aspects of tumors of the ampulla of Vater. Endoscopy 1988;20(Suppl 1):211-17.

15 Caldas C, Hahn SA, Hruban RH, Redston MS, Yeo CJ, Kern SE. Detection of K-ras mutations in the stool of patients with pancreatic adenocarcinoma and pancreatic ductal hyperplasia. Cancer Res 1994;54:3568-73.

16 Hruban RH, van Mansfeld ADM, Offerhaus GJA, van Weering DH, Allison DC, Goodman SN, et al. K-ras oncogene activation in adenocarcinoma of the human pancreas. A study of 82 carcinomas using a combination of pancreas. A study of 82 carcinomas using a combination of
mutant-enriched polymerase chain reaction analysis and mutant-enriched polymerase chain reaction analysis and
allele-specific oligonucleotide hybridization. Am $\mathcal{F}$ Pathol allele-specific oligo

17 Slebos RJC, Boerrigter L, Evers SG, Wisman P, Mooi WJ, Rodenhuis S. A rapid and simple procedure for the detection of ras mutations in formalin-fixed paraffin-embedded tissue. Diagn Mol Pathol 1992;1:136-41.

18 Warshaw AL, Gu ZY, Wittenberg J, Waltman AC. Preoperative staging and assessment of resectability of pancreatic cancer. Arch Surg 1990;125:230-3.

19 Allema JH, Reinders ME, van Gullik TM, van Leeuwen DJ, Verbeek PC, de Wit LT, Gouma DJ. Results of pancreaticoduodenectomy for ampullary carcinoma and analysis of prognostic factors for survival. Surgery 1995;117:247-53.

20 Monson JR, Donohue JH, McEntee GP, McIlrath DC, van Heerden JA, Shorter RG, et al. Radical resection for carcinoma of the ampulla of Vater. Arch Surg 1991;126:353-7.

21 Baczako $K$, Buchler M, Beger HG, Kirkpatrick CJ, Haferkamp $O$. Morphogenesis and possible precursor lesions of invasive carcinoma of the papilla of Vater: epithelial dysplasia and adenoma. Hum Pathol 1985; 16:305-10.

22 Vogelstein B, Fearon ER, Hamilton SR, Kern SE, Preisinger AC, Leppert $M$, et al. Genetic alterations during colorectal tumor development. $N$ Engl $\mathcal{F}$ Med 1988;319:525-32.

23 Bos JL, Fearon ER, Hamilton SR, Verlaan de Vries M, van Boom J, van der Eb A, Vogelstein B. Prevalence of ras gene mutations in human colorectal cancers. Nature 1987; 327:293-7. 
24 Almoguera C, Shibata D, Forrester K, Martin J, Arnheim N, Perucho M. Most human carcinomas of the exocrine pancreas contain mutant c-K-ras genes. Cell 1988;53:549-54. 25 Fearon ER. K-ras gene mutation as a pathogenetic and diagnostic marker in human cancer. 7 Natl Cancer Inst 1993;85:1978-80

26 Tada $M$, Omata $M$, Ohto $M$. Clinical application of ras gene mutation for diagnosis of pancreatic adenocarcinoma. Gastroenterology 1991;100:233-8.

27 Watanabe H, Sawabu N, Ohta H, Satomura Y, Yamakawa O, Motoo Y, et al. Identification of K-ras oncogene mutations in the pure pancreatic juice of patients with ductal pancreatic cancers. Fpn $f$ Cancer Res 1993;84:961-5.

28 Tada M, Omata M, Kawai S, Saisho H, Ohto M, Saiki RK, Sninsky JJ. Detection of ras gene mutations in pancreatic juice and peripheral blood of patients with pancreatic adenocarcinoma. Cancer Res 1993;53:2472-4.

29 van Laethem JL, Vertongen P, Deviere J, van Rampelbergh J, Rickaert F, Cremer M, Robberecht P. Detection of c-Ki-ras gene codon 12 mutations from pancreatic duct brushings in the diagnosis of pancreatic tumours. Gut 1995;36:781-7. 